\title{
Investing in Quality Early Childhood Education for Quality Indonesian Human Resources
}

\author{
Muhammad Hasbi ${ }^{1, *}$ \\ ${ }^{1}$ Director, Directorate of Early Childhood Education, The Ministry of Education and Culture. Indonesia \\ *Corresponding author. Email: muhammad.hasbi@kemendikbud,go.id
}

\begin{abstract}
Early Childhood Education (ECE) is an important foundation of quality and sustainable human life in Indonesia. The Presidential Decree Number 60/2013 on Holistic and Integrative Early Childhood Education mandates that there are five basic needs that all Indonesian children should have, namely: health, nutrition, education, care and protection. In line with it, relevant stakeholders are expected to collaborate and work hand in hand to realize quality ECE. There are at least three important parties to be involved: family or parents, educational units and health institutions. Of these three, it is important to note four things: first, the quality of the teachers, especially in establishing patterns of communication or interaction between teachers and children. Second, curriculum and methods, such as the ability to create and innovate play-based learning methods. Third, it is important to integrate health institutions in ECE units. Finally, parenting plays an essential role to stimulate children's development.
\end{abstract}

Keywords: Quality, ECE, parenting, holistic integrative

\section{INTRODUCTION}

Early childhood education and development has become a major concern of the global community, evidenced in "Sustainable Development Goals" (SDGs). The fourth target of SDG: Quality Education, particularly 4.2 highlights that access and quality of education, as well as early childhood development, is a priority. The target stipulates that "By 2030, ensure that all girls and boys have access to quality childhood development, care, and preprimary education so that they are ready for primary education".

President Joko Widodo (Jokowi), in his second period of presidential leadership, put high emphasis on the development of Indonesian human resources. On various occasions, President Jokowi stressed that human development has to guarantee children's health since pregnancy to adulthood. Therefore, ECE is expected to improve the quality of the nation.

Early childhood is a golden period of every child's development. At this golden age, every child could yield maximum stimulation in his/her growth and development. If a child does not get proper treatment, (s)he may be vulnerable to various risks. Naim et al. (2017) stated that pregnant women and children under five years are at the highest risk of micronutrient deficiencies (MNDs), such as growth issues and intellectual decline.

There is a strong impression that non-formal ECE tends to be taken for granted, and detached from the national education system. In fact, it determines children's future and growth and development as a whole. Even when they are in the womb, they have to receive special attention, because they are the real assets of the nation's future. Therefore, realizing quality ECE will certainly guarantee future generations.

Quality ECE is crucial for its fundamental role in stimulating children's growth and development, intelligence, and character or mentality.

Various studies suggest that it is vital to pay attention to human development since pregnancy until the age of eight (United Nations Children's Fund [UNICEF], 2018). This age range is considered as a critical period for the foundation of children's motor, cognitive, and social development. To ensure post-natal health, in Indonesia, there is the first 1,000 days programme. In this programme, every child in the age of 1,000 days should have access to their basic needs.

It is important to acknowledge that human learning process lasts for a lifetime. However, the best time begins at an early age. As the saying goes, "learning since an early age is like carving on a stone, while learning at old age is like carving on water". This means to say that, children have great learning potential to be create a generation. For this reason, Indonesian children should receive high attention as they are key to develop the country.

The National Scientific Council on the Developing Child (2007) identifies that early age is the age of accelerating high human capacity when compared to other age levels. Meanwhile, according to Luna et al., (2004), individuals' cognitive development is very rapid at the age of children. The development will then begin to slow down when reaching adolescence and adulthood. 
Serious commitment in realizing quality ECE is evident when the Directorate of ECE was established in 2001. Presidential Decree and Government Regulation Number 60/2013 on Holistic ECE strengthen its existence. Holistic ECE has become a national programme to realise quality ECE nationally. These national commitments emphasize that ECE has to be a concern of all stakeholders who are responsible to guarantee the five basic needs.

Furthermore, the Minister of Education Regulation Number 137/2014 on National ECE Standards was developed to strengthen the ECE programme. All ECE centers have to adhere to eight national ECE standards: children's growth and development (STPPA), content, process, assessment, facilities and infrastructure, teaching and non-teaching staff, management, and financing. This regulation is an effort to improve the quality of ECE centers.

ECE also prepares children to enter primary school. Various studies, such as UNICEF (2019); Brinkman et al., (2019) and Organization for Economic Co-operation and Development (OECD) (2017) stressed the positive impacts of ECE, especially in preparing children to enter primary school. Children joining an ECE programme will have more opportunities to develop their cognitive and non-cognitive abilities, as well as emotional intelligence and soft skills.

A longitudinal study in the United States to see the long term effects of ECE found that adolescents who previously participated in an ECE programme have a higher chance of graduating from senior secondary school, and entering higher education (Sylvia et al., 2004). They would also have better abilities to live a healthy life. This study provides an illustration that ECE can stimulate cognitive intelligence, socio-emotional skills, and learning maturity.

Concrete efforts are needed to design the necessary tools to advance the quality of national ECE. Children do not grow naturally, but need proper parenting and education, so their growth and development could be well nurtured. This parenting programme should incorporate quality ECE activities that meet the national standards.

Quality ECE stimulates children's growth and intelligence. However, if ECE is supported by poor parenting, it will undoubtedly have adverse effects, such as trauma in learning. According to Howes et al. (2008), it is necessary to ensure that the interaction of teaching and non-teaching staff with children is well entwined to provide a significant impact for the children's development. Otherwise, very little will ECE benefit their development. Quality learning interventions will function as a foundation for maturity in older children.

\section{INTERSECTORAL COLLABORATION TO REALISE QUALITY ECE}

To ensure children's quality growth and development, intersectoral collaboration is a must. In fact, it is mandated in the Government Regulation Number 60/2013 on Holistic and Integrative ECE. The literature also indicates the importance of collaboration to ensure children's development sustainably. The collaboration plays a vital role in improving children's growth. There are at least three roles that relevant sectors have to realize quality ECE for children.

The sectors with pivotal roles to achieve quality ECE are family, ECE centers and health institutions. These three have to work together and collaborate well to ensure that the basic needs of every child are appropriately met. As mandated by the Government Regulation, the basic needs encompass nutrition and health, care and education, and protection. All of these needs have to be fulfilled by the three sectors.

The sectors are also the main factors to improve children's quality of life. For this reason, intersectoral collaboration is essential. The efforts that can be done, to the least, should focus on the patterns of communication or interaction between teachers or parents and children, play-based learning, health services integration, and active parenting to stimulate children's development.

Firstly, the interaction between teachers or parents and children. By using socio-ecological frameworks, studies by OECD (2018) and RAND Corporation mention that there are two approaches to support quality ECE, namely: structure and process. The former refers to infrastructure and facilities, teacher qualification, and curriculum, while the latter is quality interaction between teachers and children, ECE activities, assessments, and learning process. Teachers also play an important role, and hence, should be of quality. According to Brinkman at el., (2017), teachers' quality cannot be seen from their academic background. No matter how good their academic background is, and if they cannot interact with children well, teachers will never provide significant impacts to the children's growth and development.

Quality interaction between teachers and children is also important, because it deals with children's psychological needs. When children are enrolled in ECE Centers, they begin to recognize adults in addition to their parents. In this context, children need (adult) role models. Children who are close with adults, such as parents, teachers and caregivers have better abilities, socialize better with peers, and show less aggressive behaviors than those who do not have positive interactions with adults around them.

Similarly, positive communication and interaction with parents will spur children's development and intelligence. Parents will become the first and foremost targets of interaction, because many children live with their parents every day. Many children also do their daily activities together with their parents. Therefore, parenting becomes a determining factor for the development and growth of children's intelligence, cognitively and psychologically. 
Excellent communication between parents or teachers and children should show positive and pleasant interactions. Secondly, play-based learning. Research consistently shows that effective methods for early childhood education are activities through play. This method is considered to be excellent in stimulating children's intelligence. In Indonesia, the Minister of Education Regulation Number $137 / 2014$ mandates every teacher to design learning activities through play. This is also suggested by the OECD (2017) and UNICEF (2018) that young children's main activities are learning through play.

When playing, various aspects of development in children will be adequately stimulated. Play activities can encourage the development of children's cognitive and socialemotional skills, as well as physical and motor development. These abilities can be illustrated by increasing intrinsic motivation, coping ability, problemsolving, self-control, following the rules of the game and building friendships. Therefore, play is an essential process for children's mental health, a critical foundation for children's development (UNICEF, 2018).

Marcon (2002) shows positive research results using a play approach for older children at school. Marcon conducted a study on $4^{\text {th }}$ grade elementary school children or six years after ECE. Marcon grouped them based on the learning model in the ECE Centre they attended. The results show that children who attend learning through play reach higher (14 per cent) than those who learn with conventional methods of fourth-grade school level. A longitudinal study supports Marcon's findings: play in pre-school activities can stimulate children to achieve excellent academic results (mathematics and reading) significantly (Sylva et al., 2004). Thirdly, the integration of health and nutrition services with ECE. Access to health and nutrition services is very significant factor affecting the academic attainment of both underprivileged and well-off children. In various countries, ECE services have been integrated with health services so that barriers interfering with children's development and development can be minimized and overcome together. For this reason, it is necessary to have ECE integrated with children's health and nutrition programmes. The integration can be interpreted as education, health, nutrition and parenting services under the same roof. Otherwise, different ECE Centers collaborate with each other to ensure the fulfilment of children's basic needs.

An example of an integrated programme is giving nutritious food in an ECE Centre. Meanwhile, an example of a coordinated programme is puskesmas or posyandu. These institutions coordinate with ECE Centers to find out information on children's health conditions, and this will be beneficial for teachers and parents.

Fourthly, strengthening the role of parents or family. Heckman (2017) argues that the family is the most important factor contributing to optimal children's growth and development. Parenting also includes competence in accompanying children in playing, having a discussion, and building literacy skills. Thus, parenting is essential to influence children's growth and intelligence. Every parent need to have those positive parenting skills to ensure their children grow and develop well.

Empowering parents about positive parenting is essential. Studies by Behrman et al. (2014) and Giallo et al. (2010) show that parenting skills could reduce the education gap at an early age. The role of parents is very significant, especially in assisting children in the learning process. Children learn and respond better to stimulations with the support of parents and family environment.

Research has shown that ECE programmes, which incorporate parenting and home visits, can improve parents' good practices in assisting children to play and learn, compared to ECE programmes that solely focus on children (Giallo et al., 2010; Whitebread et al., 2009). Love et al. (2005) found that parents whose children attend ECE are more ready to provide children with readiness to play and learn at home, can tell stories and discuss their learning progress. Therefore, positive parenting will make parents become effective partners in ensuring children's growth and intelligence.

Research by Irwanto et al. (2011) shows that children who participated in ECE generally have better cognitive development for school readiness compared to children who did not attend ECE. Children who attended ECE are also better prepared to learn independently, and are not worried when they have to separate themselves from their parents at school. They are also more ready to receive teachers' instructions in the classroom than their friends who go straight to primary school without attending ECE first. Brinkman et al. (2019) also found that children who participated in ECE longer (i.e. playgroup, then kindergarten) have higher school readiness than children who only joined playgroup or kindergarten.

These studies are consistent with the findings of studies in other countries. In Indonesia, ECE is found to have a positive impact on children's school readiness and academic attainment. However, access to ECE still needs improving so that more Indonesian children can receive the benefits of ECE for their academic attainment and holistic development.

Cognitive and social-emotional development, or what is commonly referred to as character development, is also an important feature that requires the role of ECE. Referring to previous studies, ECE can potentially improve the quality of children's learning outcomes. Therefore, access to, and quality of, ECE need to be a national concern, and are expected to improve Indonesian children's literacy and numeracy skills.

ECE is also expected to build a positive character for the character could be well developed when fostered since the early years. Character education that develops critical thinking skills and social competence can instill children's 
good habits. Character education at the ECE level is currently interpreted as good habituation in early childhood, and tends to be limited to the habituation of worship. There is no formulation of desired values/characters to be developed in ECE apart from the values that can be interpreted from STPPA (Child Development Achievement Level Standards).

Intersectoral collaboration is a great hope to improve the quality of ECE. This is based on existing conditions of Indonesia. People's low awareness on ECE affects the intersectoral collaboration. For example, Indonesian children's health condition is alarming. Badan Perencanaan Pembangunan Nasional (BAPPENAS) \& UNICEF (2017) mention that one in three Indonesian children is susceptible to stunting, and this condition will affect children's cognitive and intelligence (development). The government has taken preventive actions by issuing the Government Regulation Number 42/2013 on the National Movement to Accelerate Nutrition Improvement. In its implementation, ECE Centers play an important role as alternative places for nurseries that are holistic integrative.

In addition, there are also parenting issues. Most parents in poor condition have less parenting knowledge compared to prosperous parents. The majority of early children who were selected as subjects in this study received language stimulation from their mothers. It is their mothers who teach them to know the names of objects and important expressions, such as "thank you", "good morning", and so on. The results show that in the Indonesian context, socioeconomic status (SES) correlates with parenting skills. However, the most important aspect in early childhood education is not SES, but parenting skills (Heckman, 2013). Teacher competence in creating and applying effective play-based learning is another issue. Teacher interaction is an important factor: their academic qualification will not help the quality of their communication and interaction with children. It is important for ECE Centers to have interactive and creative teachers. The ECE Centers have to ensure that the teachers could establish interactive communication with the children.

\section{CONCLUSION}

Efforts to improve the quality of ECE in Indonesia have actually been planned for a long time as evidenced by the establishment of the Directorate of ECE, the issuance of the Government Regulation Number 60/2013, and the Minister of Education Regulation Number 137/2014. Various regulations and movements to support ECE have also been encouraged. However, what is needed is the optimization of all parties and stakeholders to improve the quality of ECE throughout Indonesia.

At the very least, the optimization can be implemented in the near future through intersectoral collaboration that focuses on improving the quality of the teachers, communication patterns or interaction between teachers or parents and children, curriculum and teaching methods (play based learning), the integration of health services in ECE Centers, and parenting programmes for parents to play an active role in spurring children's development.

\section{REFERENCES}

Badan Perencanaan Pembangunan Nasional (BAPPENAS) \& UNICEF. (2017). SDG baseline report on children in Indonesia. Retrieved from https://www.unicef.org/indonesia/SDG_Baseline_Repo rt_on_Children_in_Indonesia.pdf

Behrman, J. R., Parker, S. W., \& Todd, P. E. (2014). Preschool programs in developing countries. In Education policy in developing countries (pp. 65-106). Chicago, IL: University of Chicago Press.

Brinkman, S., Hasan, A., Jung, H., Kinnell, A., Nakajima, N., \& Pradhan, M. (2017). The role of preschool quality in promoting child development: Evidence from rural Indonesia. European Early Childhood Education Research Journal, 483-505

Directorate of ECE Development. (2013). Government Regulation Number 60 of 2013. Jakarta: Directorate of ECE Development

Giallo, R., Treyvaud, K., Matthews, J., \& Kienhuis, M. (2010). Making the transition to primary school: An evaluation of a transition program for parents.

Australian Journal of Educational \& Developmental Psychology, 10, 1-17.

Hamre, B. K., \& Pianta, R. C. (2001). Early teacherchild relationships and the trajectory of children's school outcomes through eighth grade. Child Development, 72(2), 625-638.

Heckman, J. J. (2013). Giving kids a fair chance. Cambridge, MA: The MIT Press.

Indonesian Republik. Presidential Decree and Government Number 60 Year 2013 on ECE Holistik Integratif. Jakarta: Indonesian Republik.

Irwanto., Sembiring, W. S., Widiawati, Y., \& Irwan, A. (2011). Improving school readiness through early childhood education in rural areas in Indonesia. Jakarta: Faculty of Psychology Atma Jaya Catholic University of Indonesia.

Love, J. M., Kisker, E., Ross, C., Raikes, H., Constantine, J., Boller, K., ... Vogel, C. (2005). The effectiveness of early head start for 3-year-old children 
and their parents: Lessons for policy and programs. Developmental Psychology, 41(6), 885-901.

Marcon, R. (2002). Moving up the grades: Relationship between preschool model and later school success. Retrieved May 15, 2019, from

http://ecrp.illinois.edu/v4n1/Marcon.html

Ministry of Education and Culture. Minister of Education Regulation Number 137 Year 2014 about National ECE National Standards. Jakarta: Kementerian Pendidikan dan Kebudayaan.

Naim, R., Juniarti, N., \& Yamin, A. (2017). Pengaruh edukasi berbasis keluarga terhadap intensi ibu hamil untuk optimalisasi nutrisi pada 1000 hari pertama kehidupan. Jurnal Keperawatan Padjadjaran, 5(2).

National Scientific Council on the Developing Child. (2007). A Decade of Science Informing Policy. Harvard University. Retrieved from https://developingchild.harvard.edu/science/nationalscientific-council-on-the-developing-child/.

Organisation for Economic Co-operation and Development (OECD). (2017). Starting strong V:

Transitions from early childhood education and care to primary education. Paris: OECD Publishing.

OECD. (2018). Engaging young children: Lessons from research about quality in early childhood education and care, starting strong. Paris: OECD Publishing.

Sylva, K., Melhuish, E., Sammons, P., Siraj-Blatchford, I., \& Taggart, B. (2004). The Effective Provision of PreSchool Education (EPPE) project: Final report a longitudinal study funded by the DfES 1997-2004. London, UK: EPPE Project University of London.

United Nations Children's Fund (UNICEF). (2017). Early moments matter for every child. New York, NY: United Nations Children's Fund (UNICEF).

United Nations Children's Fund (UNICEF). (2018). Learning through play: Strengthening learning through play in early childhood education programmes. New York, NY: United Nations Children's Fund (UNICEF).

United Nations Children's Fund (UNICEF). (2019). A world ready to learn: Prioritizing quality early childhood education. New York, NY: United Nations Children's Fund (UNICEF). 